\title{
Transformation Of The EU Law Related To The Etabilishment Of National Law In The England In The Law Perspective Of International Organizations
}

\section{Syaravina Lubis}

Sumatera University Faculty Of Law. E-mail: syaravinalubis@gmail.com

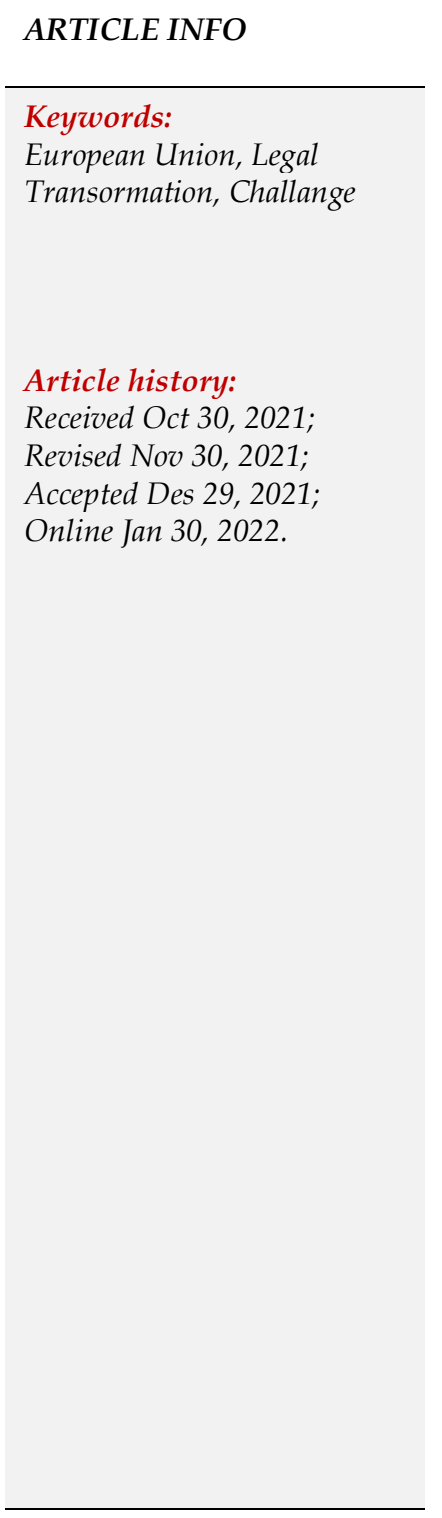

\begin{abstract}
The economic upheaval of a country is one of the reasons for the formation of an international organization, namely the European Union. The goal of the European Union itself is to promote through the community the harmonious, sustainable development of economic activity, steady improvement, rapid improvement of living standards, quality of life and closer relations between member states. This research has a problem formulation consisting of the transformation of EU law into law in the member states of the European Union, the transformation of EU law in the UK, and a challenge as a legal effort related to the transformation of EU law in the UK according to International Organization Law. This study uses a normative juridical research method. The results of the research on the transformation of European Union Law into National Law of member countries, namely by establishing Regulations, Directives, Decisions that must be applied in member countries. EU law has the supremacy of overriding the National Laws of member states. The transformation of European Union Law in the UK began with the agreement of the European Communities Act 1972 which was the UK's ratification of EU Law. Challenge as a legal remedy related to the transformation of European Union Law in the UK is permitted under Articles 230 and 232 of the European Union Agreement, namely by submitting a complaint to the national court in accordance with the time specified to carry out the challenge, this challenge action can end with an amendment. The conclusion of the research is the transformation of European Union Law in member countries in the form of Regulations, Directives, and Decisions. The European Union Law Transformation in the UK is regulated through the European Communities Act 1972. Challenge as a legal remedy related to the transformation of EU Law in the UK is allowed in order to create a good implementation. Suggestions related to research is that it is better to ensure that the transformation of European Union Law has been implemented as intended. The transformation of EU Law in the UK should ensure that UK National Law can be waived in the event of a conflict with EU Law which is immediately effective. Conduct in-depth negotiations, ask for opinions from representatives of each member country so that unity is achieved to facilitate the implementation of European Union Law in member countries and minimize challenges to European Union Law.
\end{abstract}

This is an open access article under the CC BY-NC license.

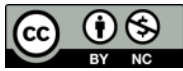

\section{Introduction}

Now the European Union has turned into the largest organization in the European region and has 28 members, namely Belgium, Bulgaria, Czech Republic, Denmark, Germany, Estonia, 
Greece, Spain, France, Ireland, Italy, Cyprus, Latvia, Lithuania, Luxembourg, Hungary, Malta, Netherlands, Austria, Poland, Portugal, Romania, Slovenia, Slovakia, Finland, Sweden, United Kingdom and Croatia who only joined in 2013.

Talking about the European Union cannot be separated from the regulations established by the European Union itself to be applied in its member countries. European law is made to support one or more of the objectives specified in the European Commission Agreement, such as promoting markets between member states or preserving, protecting, improving environmental quality. apply the laws of the European Union in their country.

European Union law is a legal system created by treaties. This independent system has been given effectiveness, through its recognition in the national legal systems of member states, and by developments in decisions in the European Court of Justice. The widening membership of this organization almost covers the entire territory of the European continent, this proves that the European Union is a very large organization. Since the organization was first formed, it has produced many legal regulations to be implemented in each member country. This widening of membership has led to problems in several European countries in interpreting EU regulations. This often leads to errors in enforcing EU law itself.

This event can occur due to the obligation of member states to comply with EU law and national laws of member states cannot overturn EU law. The problem in the relationship between EU law and national law is not unique. There is no difference from the question of the relationship between international law and national law which so many jurists have done over a long period of time. It is usually treated as a separate distinction and issue because EU law is more of a loose federal law than international law because many of its regulations reflect national ideas of administrative law and therefore involve a lot more private law than usual. However, it is not necessary to solve this problem, the reason being that in this context, from the point of view of EU law, it is highly exalted and should give effect to national law.

The law is established by the European Commission, then discussed and concluded by the Council of Ministers after consultation with the European Parliament.9 Each of these institutions is represented by each member state.10 The ratification of these provisions is formed based on the number of representatives of each country that contributes votes. 11 This is prove that the formation of these provisions with a fair method to prevent In this study, we will discuss more about the application of European Union Law in the UK. The UK joined the European Community (now known as the European Union) on January 1, 1973. The obligation to incorporate EU Law into UK law is through the European Communities Act 1972. EU law adopts an approach in which EU law takes precedence over national law. But English law tends to two approaches. Thus, treaties executed by the UK, require legislation to be enforceable. Rules of international law only form part of British law if they are accepted and adopted by the UK. Since the joining of the UK into the European Union, many EU regulations have been implemented by the UK.

All rights, powers, responsibilities, obligations and prohibitions from time to time created or arisen under the agreement, pursuant to which agreements without prior authorization to be given legal force or used in the UK must be recognized, available in law and enforceable, permitted and followed in accordance with the meaning of the enforcement of community rights and similar expressions should be read as reference to one and the other to which this paragraph applies (Article 2(1) European Communities Act 1972).

With the article mentioned above, is it possible that the EU provisions are ignored because they are not in accordance with the wishes desired by the UK, the answer is no, but the UK can negotiate where they object to, namely by challenging the EU legislation, this can be done only if the regulation does not reflect the object of the treaty or is not based on the powers deriving 
from the treaty, then national courts can use domestic measures that implement it. The incorporation of general principles into legislation was still very foreign to the UK, however these general principles have influenced the development of general principles in the European Court of Justice.

\section{Method}

The research carried out in discussing the formulation of the problem in this thesis is through a normative juridical approach. Normative juridical research is a research method that refers to legal norms contained in laws and regulations and judges' decisions in the trial process.13 This research uses normative juridical methods to examine applicable international legal norms regarding the European Union, which are contained in in international conventions, such as the Treaty on the European Union, the European Communities Act 172.

The method of data collection was carried out by means of library research, namely research conducted by examining library materials or so-called secondary data. The secondary data used in this study, among others, came from books from private collections and borrowed from libraries, articles from both print and electronic media, government documents, including laws and regulations and international agreements. the data analysis used is a qualitative approach to secondary data analysis.

\section{Analysis And Results}

\subsection{Transformation Of Eu Law In The Uk}

a. A Brief History of the UK and its Entry into the European Union

\section{1) A Brief History of England}

The territory of England was first inhabited by modern humans during the Paleolithic period, but the name England comes from the Angles, who were one of the Germanic tribes who settled there in the 5th and 6th centuries. England became a unified nation in AD 927, and since the Age of Discovery began in the 15th century, it has exerted significant cultural and legal influence on many parts of the world. The English language, the Anglican Church, and English law - which form the basis of common law systems for other countries around the world-originated and developed in England, and the country's parliamentary system has also been adopted by many other countries. The Industrial Revolution that began in the 18th century made England the world's first industrial nation.

In 1921, the British Empire included a population of between 458 million people, approximately a quarter of the world's population, and spanned over 36 million $\mathrm{km}^{2}$, about a quarter of the earth's total area. Although these territories have now developed into the Commonwealth of Nations, Britain's influence remains strong around the world in economic practice, law and government systems, society, sport.

England has existed as a unit since the 10th century, the union between England and Wales, started in 1284 with the Statute of Rhuddlan, was not formalized until 1536 with the Act of Union, in the Act of Union 1707, England and Scotland agreed to join as permanent England, the legislative union of Great Britain and Ireland were implemented in 1801, with the adoption of the names Kingdom of Great Britain and Ireland, the Anglo-Irish treaty of 1921 formalized the partition of Ireland, the six counties of Northern Ireland remained part of England as Northern Ireland and the current name of the country, United Kingdom Great Britain and Northern Ireland, 
adopted 1927.

The United Kingdom of Great Britain and Northern Ireland was formed from the United Kingdom of Great Britain and Northern Ireland. The other countries are Scotland, Wales and Northern Ireland. Often the English name is used to refer to the entire country. England is a country that is part of the United Kingdom. The country of England is bordered by Scotland to the north and Wales to the west, the Irish Sea to the northwest, the Celtic Sea to the southwest, and the North Sea to the east and the English Channel, which separates it from continental Europe, to the south.

The United Kingdom is a constitutional monarchy and parliamentary democracy, with the Queen and a parliament having two houses: the House of Lords, with 574 associates, 92 hereditary associates, and 26 bishops, and the House of Commons, which has 651 members. selected. Supreme legislative power is vested in parliament, which sits for five years unless it is dissolved sooner. The House of Lords was stripped of most of its powers in 1911, and now its main function is to revise laws. In November 1999, hundreds of fellow descendants were expelled in an attempt to make the body more democratic. The executive power of the Crown is exercised by a cabinet headed by the prime minister.

2) he entry of the UK to become a member of the European Union

Not long after PM Harold Macmillan (Conservative Party) on July 31, 1961 stated that he would apply for UK membership in the European Union, official negotiations began between Britain and the European Union to agree on UK membership. But the negotiations There are obstacles especially when discussing the agricultural sector which is very sensitive in many EU member states. England imports all of its agricultural products so there is no need to protect its agricultural products. This is in stark contrast to other EU member states which are very interested in protecting their agricultural products. Farmers in continental Europe have long received preferential treatment from the governments of their respective countries and are isolated from the world market because European farmers' incomes are relatively low while production costs are very high. The protracted negotiation process between Britain and the European Union has strengthened French President Charles de Gaulle's belief that Britain and the European Union countries are very different. De Gaulle fears that the trademarks brought by Britain and other countries that will follow suit will change the agreement that France and the six original European Union members have made. These concerns reached their peak when Britain signed a defense agreement with the United States on December 21, 1962.

With this agreement, Britain gave up its nuclear defense rights to the United States so that if Britain became a member of the European Union, the United States would automatically have direct influence over the European Union. This development certainly became a threat to France, which wanted Europe to be free from the influence of the United States, so on January 14, 1963, President Gaulle decided to veto Britain's membership in the European Union. At that time, Britain's membership was only a matter of time, but France's veto prevented Britain's entry into the European Union Failed with the first membership, Britain who was in the government of PM Harold Wilson (Labor Party) again applied for EU membership in April 1966. At that time, the problems that had plagued him in 1961-1963 such as agriculture and the Commonwealth were relatively resolved. Britain promised that its membership would not change the foundations of the European Union, even though Britain's entry was a synergy for Western Europe. This British effort was again blocked by President de Gaulle, who again proposed a veto in May 1967. 
President de Gaulle still thinks Britain is not ready to join the European Union because of the special relationship between Britain and the United States. In addition, there are also doubts among European Union members who are worried that the British economy will also be burdened. So Britain's attempt to become a member of the European Union failed again. It is clear that as long as de Gaulle is president of France, British membership in the European Union is impossible. Under this constitutional approach, a rule of customary international law, or a rule established by an international treaty to which the country is a party, automatically becomes part of the national law of that country. Therefore, once a country has signed an agreement that guarantees certain rights in its national territory, those rights will automatically be protected by national law. For example, the constitutions of France and the Netherlands can be called monoist constitutions. A dualist constitution, which is the category to which the British constitution generally falls, is one in which there is only a limited number of statuses relating to the rule of international law,

\section{b. The Relationship Between European Union Law and British Law According to European Communities Act 1972}

The EU Treaty in the UK was ratified through the establishment of the European Communities Act 1972 by the UK House of Parliament, and entered into force on 1 January 1973 in the UK.80 Under the European Communities Act 1972 (1972 Act), the UK adopted the provisions of the Treaty, but did not adopts a rigidly monoist approach (leaving the courts and administrations not to misimplement the implications of the Treaty) and also does not adopt a very specific dualist approach that is, detailing precisely the changes that will occur to English Law under the Treaty. He has chosen the middle path and adopted the European Communities Act 1972 flexibly.

Section 2 of the 1972 Act describes the difference between the enforcement of rights and obligations in the UK under treaties having a direct effect on the domestic law of member states and the enactment of parts of European Union law that require implementation by member states. 1972 Act is to take full effect in the UK. Gave effect through the legislative delegation process under the 1972 Act. This agreement relates to the rights and obligations of the UK to enforce a set of European Union Laws which have immediate effect without needing to be promulgated. But the lines of distinction are not clear, with the main issue being whether provisions of EU law have a direct and reliable effect on courts without being given legal force by delegated legislation.

Article 2(1) 1972 Act leaves matters for consideration under European Union Law, British Courts may, and in some cases must, submit inquiries to European Courts under Article 234 of European Union Law. with European Union Law. There are two points of general character which should be made at the beginning. First, the 1972 Act was not incorporated entirely from EU Law into UK Law unless specifically provided for by statute or subordinate legislation, only those provisions of this EU Law which EU Law is directly applicable or effective in member states have directly become part of British law.

It cannot be argued that the distinction was reviewed by the European Court of Justice, but it has been used by the General Advocates to show that the provisions of the regulation are directly applicable under Article 249 of European Union law but are not immediately effective and that the directive is not directly applicable under Article 249 but can be immediately effective. But at times, the concept of direct effect has nothing in common with the notion of a 'self-executing' agreement. 
In general, under Article 2(1) of the 1972 Act, the laws of the European Union, whether created by the Treaty or EU Regulations, and whether such laws already exist or are to be enacted in the future, will have immediate effect in the UK. without the need for a law to be passed by the British Parliament at any time. Therefore, he recognizes the principle that the Agreement must determine the limits of the rights these rights in the UK and allow for the immediate exercise of these rights in the UK.

In addition, under Section 2(4) of the 1972 Act87, any legislation (and this is broad enough to include a statutory instrument) issued, or to be issued in the UK must be described with respect to the directly applicable EU law. Therefore, there is a presumption that UK statutory law should be considered subject to EU law. Thus, if there is a conflict between EU law and UK domestic law, EU law will override domestic law if the former is directly applicable. Several recent cases appear to have emphasized the supremacy of EU law over national law.

In the Duke case against GEC Reliance Ltd, the House of Lords reiterated their previous position that they would not knowingly misinterpret the meaning of UK law in order to enforce an EU Directive or Directive against an individual, if the Instruction had no direct effect on the individual. What the other Chair of the Judiciary Council supports Article 2(4) 1972 Act applies and is only applied if the provisions of the European Union are directly applicable.

\section{c. EU Legal Transformation Procedures in the UK}

The following are the main sources on the transformation procedures to which member states such as the UK already have EU rights and obligations:

1) European Union Treaty, 1993 Maastricht Treaty, 1997 Amsterdam Agreement, 2009 Lisbon Treaty

2) EU Council and Commission Regulations

Directly applied regulations are the basis for the common market. The regulations of the Council and the Commission fall within the scope of Article 2(1) 1972 Act i.e., they are responsible for establishing the rights, powers, responsibilities, obligations, prohibitions which arise from the treaty and which are pursuant to the treaty article 249 of the EU Treaty without promulgation. in advance to give effect to law in the UK. As a result of Article 2(1) 1972 Act, Article 249 of the EU Treaty will be effective in the UK incorporated in EU regulations into UK Law. The immediate effect of the regulation is now widely accepted that although Article 249 of the Regulation is directly applicable in the case that national legislation is not required to implement the Regulation, and does not need to be immediately effective in the case that the Regulation is in all cases granted direct rights to individuals. Implementation of regulations in national law, is limited to the scope of the state implementing legislation and administration. The European Court of Justice has established in several important decisions that member states are prohibited from changing the scope of EU regulations in applying their provisions.

3) EU Council and Commission Directives or Instructions

By means of the Directive that member states can be given general guidance by EU institutions. Article 249(3) of the EU Treaty says that a directive must be binding, as a result to be achieved, on each member state to which it is addressed, but must be left to national authority in choosing its form and method. An indirect directive can be applied as a regulation. A directive requires member states to change their laws, but it is left to states to implement with appropriate national legislation. It must be implemented by national law, and not simply by changes in administrative practice.94 When national legislation has enacted implementing a Directive, so court national in lower Duty for interpret legislation to achieve the results required by the Directive. Following are the obligations of member states under Article 249(3) of the EU Treaty to achieve that outcome and of their duties in. 
4) European Union Council and Commission Decisions

Decisions can be addressed by the Council or the Commission to one or more member countries or to individuals. In the case of direct decisions to member states, in normal circumstances member states will, if necessary, rely on national legislation to bring them into effect directly through states.

5) Binding European Court decisions

Article 10 of the Treaty of the European Union obliges member states to take appropriate steps, whether in general or in particular, to ensure the implementation of obligations arising from this treaty or as a result of steps taken by institutions of the European Union, and there are other provisions requiring states to members to incorporate or modify their own laws.

\subsection{Challenge As A Legal Effort Related To The Transformation Of Eu Law In The Uk}

\section{a. The Background of the Challenge}

Through Article 226 of the EU Treaty: "If the Commission considers that a Member State has failed to fulfill an obligation under this Treaty, it shall deliver a reasoned opinion on the matter after giving the State concerned the opportunity to submit its observations. If the State concerned does not comply with the opinion within the period laid down by the Commission, the latter may bring the matter before the Court of Justice."

Based on the article above, it can be explained that if according to the Commission that a member country has failed to fulfill an obligation in the Treaty, the country concerned provides its observations, then the Commission gives its opinion, if the observations of the country concerned are not in accordance with the opinion of the Commission, then the next step is to take the matter to the Court.

Most complaints against member states do not reach the European Court of Justice. By the 1980s, the Commission was aware of 500 violations annually. In 1988 the reasons for opinion were presented in 227 cases, and continued to be brought before the courts in 73 cases. In that year the Court issued 54 decisions in cases under article 226 notifying member states of breach of their obligations, and 32 cases were removed from registration in court because member states had substantially fulfilled their obligations after the proceedings began.

The conditions of the application of Article 226 namely, the Commission has taken the view that the member state has violated its obligations, the state concerned has been informed of this view and given the member state the opportunity to answer allegations or regret their wrongdoing which has in fact violated the obligation, the Commission has given an opinion to its effect, a member state has failed within the time limit set by the Commission to fulfill its treaty obligations, and the Commission has brought the matter before a court.

Despite the general view that the UK is less than fully supportive of the European Union, the number of misconduct brought by the UK has been very low. Thus the total brought before the European Court of Justice against the UK between 1986 and 1988 was 3, compared to Italy's 53. In the 1980s, proceedings against the UK have resulted in adverse judgments namely, unlawful bans on imports of potatoes, milk, chicken meat and eggs, clothing and other objects, failure to comply with Council regulations requires the use of a tachograph or a spy in a truck. For taxation and wine discrimination, for unlawful unilateral fisheries conservation measures, for failure to implement directives on value added tax and on motor vehicle headlights,

b. Requirements for a Challenge to European Union Legislation 
Article 230(2) of the EU Treaty contains that, in certain circumstances an individual may challenge EU law, through a process determined by the time limit specified in article 230(3).

Here are the requirements for doing the challenge:

1) Articles that can be retested or reviewable acts. This is not limited to regulations, directives, decisions or decisions. The European Courts are more focused on content than form and will consider all actions by institutions which are designed to have legal effect. In addition, there are others that are more obscure, sections of acts which none of the above but have sufficient legal force to make them subject to annulment. Only actions that are expressed irreversibly are recommendations and opinions that have no legal force.

2) Right to challenge. Article 230 of the Treaty of the European Union The right to challenge is limited to:

a) Member States, Councils and Commissions of the European Union

b) individually, under certain circumstances

\section{c. Procedure to Challenge EU Legislation}

Regarding the procedure for carrying out this challenge, it is not much different from the requirements for doing the challenge as mentioned in the previous section. The following is the procedure for challenging EU legislation:

1) There is a basis for doing the challenge. Under article 230 of the European Union Treaty, four basic substance for re-examination:

a) Lack of competence. The basis of jurisdiction is basically to complain that the wrong entity has acted or the right entity has done something that it does not have the legal power to do. On the basis that the wrong person, i.e. someone who is not a member of the commission, has made the decision and because of that there is a lack of competence or jurisdiction.

b) Violation of important procedural requirements.

The requirement that institutions adopt bound measures must follow a rigorous procedure. Procedures can be set out either in the EU Treaty or in secondary legislation. Most of the actions have used Article 253 (before the amendment to Article 190)109 which contains that the decision of the Commission must state the reasons on which it is based.

c) Violation of the European Union Treaty or other regulations relating to its application. The basis of this denunciation is broadly designed to include the provisions of all relevant treaties, secondary statutes adopted under the Treaty and the general principles recognized in the laws of the member states.

d. Challenge As a Legal Effort Regarding the Transformation of European Union Law in the UK According to the European Communities Act 1972 which is International Organizational Law

Britain signed the Treaty of Acceptance on January 22, 1972, then the UK officially became a member of the European Union on January 1, 1973.111 So with the UK's membership in the European Union as stated in section 2 of the 1972 Act illustrates the difference between the application of rights and obligations in the UK under the treaty- treaties have a direct effect on the domestic law of member states and the enforcement of parts of European Union law that require implementation by member states.112 In article 2(1) 1972 the Act states that all rights and obligations have been incorporated into English law. First, rights and obligations are listed as rights, powers, responsibilities, obligations and prohibitions. Second, they include 'fixes and procedures'. Third, they are known and available in law and enforced, permitted and followed accordingly. But very importantly, whether rights and powers or responsibilities or obligations or prohibitions can be enforced depends on European Union law (as based on agreements without prior promulgation to take effect in the UK). Thus, not only the provisions of the 
treaties themselves and the secondary legislation or secondary legislation made under them must be taken into account, but also the effects of legal provisions by the European Courts.

\section{Conclusion}

The process of transforming EU Law into Law in EU member states is through the establishment of legal instruments in the form of Regulations, Directives, Decisions, and Recommendations or opinions. It is important to note that EU Law takes precedence over national law to ensure that EU Law is applied in member states. There are three types of implementation of European Union Law, namely direct or direct applicable, direct or indirect effects, and indirect or indirect effects.

The process of Transforming EU Law into National Law in the UK is through Regulations, Directives, Decisions, and Recommendations or Opinions. Through the European Communities Act 1972, the European Union Treaty became part of European Union Law so that the UK enforced the legal instruments that emerged from the agreement.

Challenge as a legal remedy related to the transformation of European Union Law in the UK is based on article 230, the UK can submit a challenge within the time limit specified by the Article and negotiate where they object to, this can be done only if the regulation does not reflect the object of the agreement or not based on the power that comes from the agreement, it can submit a challenge to the national court which will forward it to the European Court so that the legislation can be followed up and amended. This challenge action does not violate the Law of International Organizations.

\section{References}

Kent, Penelope, Law of the European Union, third edition, Longman, Great Britain, 2001.

De Cruz, Peter, Comparison of Civil Law, Common Law, and Socialist Law Systems, Nusa Media, Jakarta, 2010.

Collins, Lawrence, European Community Law in the United Kingdom, fourth edition, Butterworths, Surrey, 1990.

Geddes, Andrew, Britain and the European Union, Palgrave Macmillan, China, 2013.

Gidddings, Philip and Gavin Drewry, Britain in the European Union, Palgrave Macmillan, USA, 2008.

Kaczorowska, Alina, European Union Law, Routledge-Cavendish, Great Britain, 2009.

Vincenzi, Christopher and John Fairhurst, Law of the European Union, third edition, Longman, Great Britain, 2002.

Lasok, D and JW Bridge, Law and Institution of the European Communities, fourth edition, Butterworths, Great Britain, 1987.

Kenner, Jeff, European Union Legislation 2009-2010, Routledge, Great Britain, 2010.

DW QCLLD, Bowett, International Organizational Law, Sinar Graphic, 2007.

Mauna, Boer, International Law Definition, Role, and Function in the Era of Global Dynamics, Alumni, Bandung, 2001.

Starke, JG, Introduction to International Law 1, tenth edition, Sinar Graphic, Jakarta, 2010.

http://www.kumpulansejarah.com/2013/03/sejarah-awal- founding-country-england.html 
http:/ /news.bbc.co.uk/2/hi/EUrope/8160808.stm

http://www.leeds.ac.uk/law/hamlyn/European Union.htm.

http://europa.eu/about-eu/basic-information/decision- making/treaties/index_en.htm

http://parliament.uk/documents/commons-information- office/p14.pdf

http:/ /ec.europa.eu/eu_law/introduction/what_regulation_en.htm.

http://en.wikipedia.org/wiki/Regulation_\%28European_Union\%29.

http://en.wikipedia.org/wiki/Directive_\%28European_Union\%29.

http://en.wikipedia.org/wiki/Decision_\%28European_Union\%29.

http://europa.eu/legislation_summaries/institutional_affairs/ decisionmaking_process/ai0036_en.htm http://www.britannica.com/EBchecked/topic/196004/European- Coal-and- Steel-Community-ECSC

http://www.eurofound.europa.eu/areas/industrialrelations/dictionary/definitions/acquiscommunauta ire.htm.

http://kajianeropa.wordpress.com/institution/

http://www.dadalos-europe.org/int/grundkurs4/eu-structure_1.htm 